\title{
ERROR IN VOWEL PRONUNCIATION MADE BY INFORMATICS STUDENTS
}

\author{
Nurul Frijuniarsi \\ Program of Informatics, Faculty of Technique Information and Computer, \\ University of Indraprasta PGRI \\ Jalan Nangka No. 58C Tanjung Barat, Jagakarsa, South Jakarta 12530 \\ frijuniarsinurul@gmail.com
}

\begin{abstract}
The purpose of this study is to figure out the dominant factor causing the errors of vowels pronounced by second-semester students of Informatics which is basically nonnative speakers of English. The approach applied in this study is qualitative. The data were collected via observation and recording which were constructed in the form of field-notes then analyzed and measured in accordance to English phonetic transcription in "English Pronouncing Dictionary" written by Jones (1997). This study involved 40 students of Informatics English subject at Informatics Program of Indraprasta PGRI University where English is only supporting subject. The data shows that the respondents were really lack of English pronouncing skill, especially vowels as 42 of 58 words containing vowels are pronounced incorrectly. As the result of study, we can conclude that the dominant error made by students is Interlingual errors $(58,6 \%$ or 838 of 1.430 errors made by students), the errors occurred due to the interference of students' native language.
\end{abstract}

Key words: error analysis, vowels, pronunciation

\begin{abstract}
ABSTRAK
Penelitian ini bertujuan untuk menemukan faktor dominan dalam kesalahan pengucapan bunyi vocal yang dilakukan oleh mahasiswa semester dua program Studi Informatika yang pada dasarnya bukan penutur asli Bahasa Inggris. Penelitian ini menggunakan pendekatan kualitatif. Teknik pengumpulan data dilakukan melalui observasi dan perekam suara. Data kemudian ditranskripsi ke dalam bentuk phonetic writing yang mengacu pada kamus penulisan fonetik Bahasa Inggris yang ditulis oleh Jones (1997). Penelitian ini melibatkan 40 mahasiswa pada mata kuliah Bahasa Inggris Informatika di Program Studi Informatika Universitas Indraprasta PGRI, dimana Bahasa Inggris bukanlah mata kuliah keahlian khusus. Data menunjukkan bahwa kemampuan responden dalam mengucapkan kata dalam Bahasa inggris khususnya bunyi vokal sangat kurang. Hal ini terlihat dari 42 dari 58 kata yang mengandung bunyi vokal diucapkan dengan tidak tepat. Penelitian menunjukkan bahwa faktor dominan yang menyebabkan kesalahn dalam pengucapan bunyi vokal adalah Interlingual errors (sebanyak 58,6\% atau 838 dari 1430 kesalahan), yaitu eror yang terjadi akibat interfensi atau pengaruh dari bahasa ibu.
\end{abstract}

Kata kunci: analisis kesalahan, bunyi vokal, pengucapan 


\section{INTRODUCTION}

Learning English as a foreign language has been a priority at any level of education in Indonesia, from lower to higher education. At the university level, students are required to be able to learn English not only in the area of grammar and structure but more on the skills: speaking, reading, writing, and listening. Among of the skills, speaking seems more complicated than the others. We easily find status or posts written in English at social media regardless of grammar or structure appropriateness, but it is hard to find people confidently speak English for their daily conversation. It is due to the fact that to be able to speak English fluently, students need more than just understanding or comprehension of the theory. Speaking process involves the production of sounds using speech organs and it requires continuous practices. Someone is considered speak fluently if he can produce good pronunciation on his utterances because it directly affects his communicative competence and performance (Gilkajani, 2012).

In teaching pronunciation, a teacher should be creative to find effective ways in order to make the students easily understand the material (Fraser in Gilkajani, 2012). Reading aloud can be used as a tool of practicing pronunciation. Reading aloud is an oral matter and need full understanding of letters to produce the right voice which has meaning and sense of context in the text (Afifah, 2014). When non-native students attempt to learn the pronunciation of English, there are some difficulties they may encounter; the students have to learn to recognize the speech sounds occurring in the language certainly and learn to produce those foreign sounds with their own organs of speech. The students then have to learn to use those sounds in the proper place and usage in the matter of attributes (length, stress, pitch, and manner). Furthermore they have to learn to contact sounds and join them in sequence fluently (Jones in Afifah, 2014).

The difference of language features between Bahasa Indonesia and English may cause difficulty in learning this foreign language for Indonesian students, and it will guide to production of error (Frijuniarsi, 2016). For example, English has twelve vowels while Indonesian has only six, there are no vowel a:, æ, $\varepsilon$ :, i:, o:, $\mho$, in Indonesian pronouncing. The concept of short and long vowel does not exist in Indonesian, hence these kinds of sounds will be probably considered the same by Indonesian students. Although errors made by the students are not always the results of native language interference, but it also may be caused by the intralingual factor (Husada, 2007). Production of errors normally happens in the learning process, because errors are natural part of learning a language and can work as an insight into the tools and the process used to learn a language (Corder in Afifah, 2014). In EFL course, error analysis can be used by the teacher as an useful method to help them predict and understand the pronunciation difficulties faced by their students, while for the students, it is also important to make them aware of the differences between their native language and second language during the learning process (Yiing, 2011).

According to Nurjanah, Anggoro, and Dwiastuty (2017), the term of error refers to any wrong-doing made by someone while constructing grammar or other language features as the result of his ignorance or incomplete knowledge about that language. It is certainly different to those produced 
because of slip which is called as mistakes. In the other hand, Richard cited in Heydari and Bagheri, (2012) stated that based on the source, error can be classified into: (1) Interference errors: errors resulting of the use of elements from one language while speaking/writing another language. (2) Intralingual errors: errors reflecting general characteristics of the rule learning such as faulty generalization, incomplete application of rules and failure to learn conditions under which rules apply, and (3) Developmental errors: errors occurring when learners attempt to build up hypothesis about the target language on the basis of limited experiences. Later on, Richard cited in Heydari and Bagheri, 2012) classified error according to their causes: (1) Interlingual errors: errors caused by mother tongue interference. (2) Intralingual and developmental errors: errors occur during the learning process of the second language at a stage when the learners have not really acquired the knowledge, in addition, errors are also caused by the difficulty or the problem of language itself.

The alphabets of English and Bahasa Indonesia are the same in quantity but different in the way they are pronounced. As stated before, pronunciation is the matter of sounds, the production of sound using speech organ with certain manner. English has 24 consonants, a kind of voiced and voiceless sound, in which the air stream and obstructed through a narrowing or complete closure of the mouth passage (Suparman in Afifah, 2014) English consonants are symbolized as follow: $b$, $\mathrm{p}, \mathrm{d}, \mathrm{t}, \mathrm{g}, \mathrm{k}, \mathrm{v}, \mathrm{f}, \theta$, б, z, s, 3, , m, n, n,l, $\mathrm{r}, \mathrm{d} 3, \mathrm{t} \int, \mathrm{h}, \mathrm{j}, \mathrm{w}$.

Table 1

English Consonants (Jones, 1997)

\begin{tabular}{|c|c|c|c|c|c|c|c|}
\hline \multicolumn{8}{|c|}{ Classification of NAE Consonant Phonemes } \\
\hline \multirow{2}{*}{$\begin{array}{l}\text { Manner of } \\
\text { Articulation }\end{array}$} & \multicolumn{7}{|c|}{ Place of Articulation } \\
\hline & Bilabial & Labiodental & Dental & Alveolar & Palatal & Velar & Glottal \\
\hline $\begin{array}{l}\text { Stop } \\
\text { Voiceless } \\
\text { Voiced }\end{array}$ & $\begin{array}{l}\mathrm{p} \\
\mathrm{b}\end{array}$ & & & $\begin{array}{l}\mathrm{t} \\
\mathrm{d}\end{array}$ & & $\begin{array}{l}\text { k } \\
\text { g }\end{array}$ & \\
\hline $\begin{array}{l}\text { Fricative } \\
\text { Voiceless } \\
\text { Voiced }\end{array}$ & & $\begin{array}{l}f \\
v\end{array}$ & $\begin{array}{l}\theta \\
\partial\end{array}$ & $\begin{array}{l}5 \\
z\end{array}$ & $\begin{array}{l}5 \\
3\end{array}$ & & $\mathrm{~h}$ \\
\hline $\begin{array}{l}\text { Affricate } \\
\text { Voiceless } \\
\text { Voiced }\end{array}$ & & & & & $\begin{array}{l}\text { t } \\
d 3\end{array}$ & & \\
\hline $\begin{array}{l}\text { Nasal } \\
\text { Voiced }\end{array}$ & $\mathrm{m}$ & & & $\mathrm{n}$ & & D & \\
\hline $\begin{array}{l}\text { Liquid } \\
\text { Voiced }\end{array}$ & & & & I & $r$ & & \\
\hline $\begin{array}{l}\text { Glide } \\
\text { Voiced }\end{array}$ & w & & & & $y$ & & \\
\hline
\end{tabular}

This language also has 12 vowels, a set of voiced sounds in which air leaves the mouth with no interference and which occur in similar position (Ilzamudin, 2001:43 as cited in Afifah, 2014) they are: $\Lambda, \mathrm{a}:$, æ, e, ə, $\varepsilon:$, I, i:, p, ॰:, $, \mathrm{u}:$ This kind of sounds is classified by tongue height, tongue position and lips rounding as can be seen in the following chart.

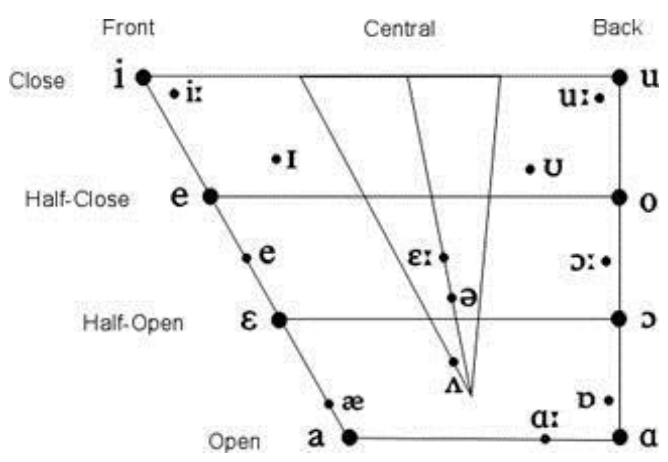

Figure 1

English Vowels Chart (Jones, 1997)

English also has eight diphthongs, sequences of two vowel sounds together in the same syllable (aI, av, əv, ei, oi, əe, iə, uə). It does not differ alot to Bahasa Indonesia. Bahasa Indonesia has 21 consonants ( $\mathrm{p}, \mathrm{b}, \mathrm{t}, \mathrm{d}, \mathrm{k}, \mathrm{g}, \mathrm{f}, \mathrm{v}, \mathrm{m}, \mathrm{n}$, $\mathrm{r}, \mathrm{s}, \mathrm{l}, \mathrm{h}, \mathrm{j}, \mathrm{c}, \mathrm{w}, \mathrm{y}, \mathrm{z}, \mathrm{\eta}, \mathrm{x}), 6$ vowels (a, $\mathrm{I}, \mathrm{u}, \mathrm{e}$, ,, $\mathrm{o}$ ) and 3 diphthongs (ai, au, oi,) . There are several sounds of English do not exist in Bahasa Indonesia, such as vowels $a$ :, æ, $\varepsilon$ :, i:, $p$, $\mho$, and the absence of that particular 
sounds in students native language might lead to difficulties in producing those sounds. Indonesian EFL learners will try to produce those kind of sounds by pronounce the most common sounds to their tongue or find the nearest equivalents to substitute those new sounds. (Yiing: 2011). Many studies shown that pronunciation errors of English made by the students from different language backgrounds are systematic and not accidental (Rajadurai in Husada, 2007). They seem to repeat the same errors as if they have acknowledged those errors as an appropriate concept: they substitute the sounds that they don't have in their native language, with other sounds which are close to them in the place of articulation e.g. they replace $/ \mathrm{p} /$ with /b/, / $\theta$ / with /s/ (Nunan and O'Connor as cited in Hassan, 2014). In another side, for EFL students, especially Indonesian students, the inconsistence of English letters in referring certain sounds also contribute to the production of error in pronunciation as stated once that there is no direct relation between letter and sounds of English and phonemegrapheme relationship in English is highly unconstrained (Perry, Ziegler and Coltheart cited in Ali, 2015).

The emphasizing on vowels rather than consonants in this study is because of the importance of these sounds in learning English. Furthermore, most of English words contains vowel, hence the correct pronunciation of words mostly depends on the pronunciation of vowel sounds. This fact suggests that pronunciation problems of English vowels can affect the meaning of words leading to intelligibility problems (Ali, 2015). Recently, the pronunciation of English vowels has gained more attention from language teachers and researchers who are interested in the learning and teaching of English as a second or a foreign language (ESL/EFL), and several studies have been conducted to classify the cause and source of error in production of vowels for later to find interpretation of many learning problems of vowel sounds (Ali, 2015). It will be useful for creating the best method to teach English vowels and consonant as well. Moreover, the error of pronouncing error will be analyzed and classified into two categories according to their cause: (1) interlingual error and (2) intralingual and developmental error (theory by Richard cited in Heydari and Bagheri, 2012). The researcher aims to find the most influencing factor contribute to the errors of vowel pronunciation.

\section{METHOD}

This study is designed by using the descriptive qualitative method, because it is basically trying to analyze, describe, and explain the data. Furthermore, the findings of this study are revealed not by tools of statistical procedures or other devices of quantification (Pallawa and Alam, 2013) the procedure of data collection was done by observation and recording. The samples are 40 students at English I Course of Informatics Program at Faculty of Engineering Mathematics and Science University of Indraprasta PGRI. The 40 students were given a short reading text that they have to read individually in queue while the researcher recorded it by using voicerecord application on Samsung Ace Duos Smart Phone. The data then were transcripted into phonetics writing to find out the inappropriateness pronunciation in accordance to dictionary of English phonetic system (Jones, 1997). Errors made by the students than grouped into (1) Interlangual (2) Interlangual and 
Developmental Error (Richard, 1974 cited in Heydari and Bagheri, 2012). Last, simple counting using percentage will show which kind of error dominantly made by the students.

\section{RESULTS AND DISCUSSION}

In this study, error analysis is used for describing errors made by the student while reading a short text aloud. Findings will be classified in a table according to their cause. For additional information, subjects of this study are Indonesian-spoken students, although there are some of them use their local language, in example Sundanese, Javanese, and Bataknese for communicating within family, but they speak Indonesian fluently for interacting with friends and others. 40 students are required to read the text personally, face to face to the researcher. While a student read, the others were waiting outside the room. Hence, it can be temporary concluded that every students pronunciation while reading are based on their own knowledge and skills, without interference from other students Here is the text given to the students to be read loudly:

\section{Computer Science}

Computer science is the study and development of computer technology. It includes the theory in which computer research and technology is based on system analysis design, application system software design, and programming. Concept such as algorithms and computation are central to computer science. Computer scientists focus on the technology used in building computer system. A thorough knowledge of computer hardware and software, and how they interact is a requirement for any professional in the field. To that end, a background in multiple computer languages is in demand by both hardware and software companies. In addition, networking and system administration skills are a plus.

Here is the phonetic transcription of the text above:

$$
\text { kəm’pju;tə ‘sarəns }
$$

kəm'pju;tə 'saIəns IZ də 'st $\Lambda$ dI ænd dI'veləpmənt pv kəm'pju;tə tek'nplədzI. It In'klu:dz ðә Өгəri in wit $\int$ kəm'pju;tə rI'sə:t $\int$

ænd tek'nplədzI Iz beIst 'sistim əneləsis dı'zaIn, æplı'kerfən 'sistım sofweə di'zain ænd prəograeming. 'kpnsept s $\mathrm{t} \int$ æz 'ælgərıðmz ænd 'kəmpju:'terfən a: 'sentrəl tu: kəm'pju:tə 'saIəns. kəm'pju;tə 'saIəntıst 'fəokəs on ðə tek'nolədzI ju:zd In 'bildıng kəm'pju;tə sistım. ə $\theta \Lambda$ rə nolidz kəm'pju;tə ha:dweə ænd 'softweə ænd hav deI Intər'æk IZ ə rikwaiəmənt fo:r eni

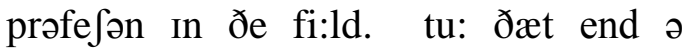
'bækgraund in 'msltipl kəm'pju;tə længwidzIz in di'ma:nd baI bəot ' ha:dweər ænd 'softweə 'kımpənIz. In ə’difən, 'netwə:kıng ænd sistım ədminıs'treIfən skılz a:r ə plıs.

The following table shows error of vowel pronunciation made by the students (regardless to the errors of consonant pronunciation).

Table 2. Errors of Vowel Pronunciations

\begin{tabular}{lllll}
\hline no Words & Transcription & Numbers and $\%$ & of & Description
\end{tabular} 


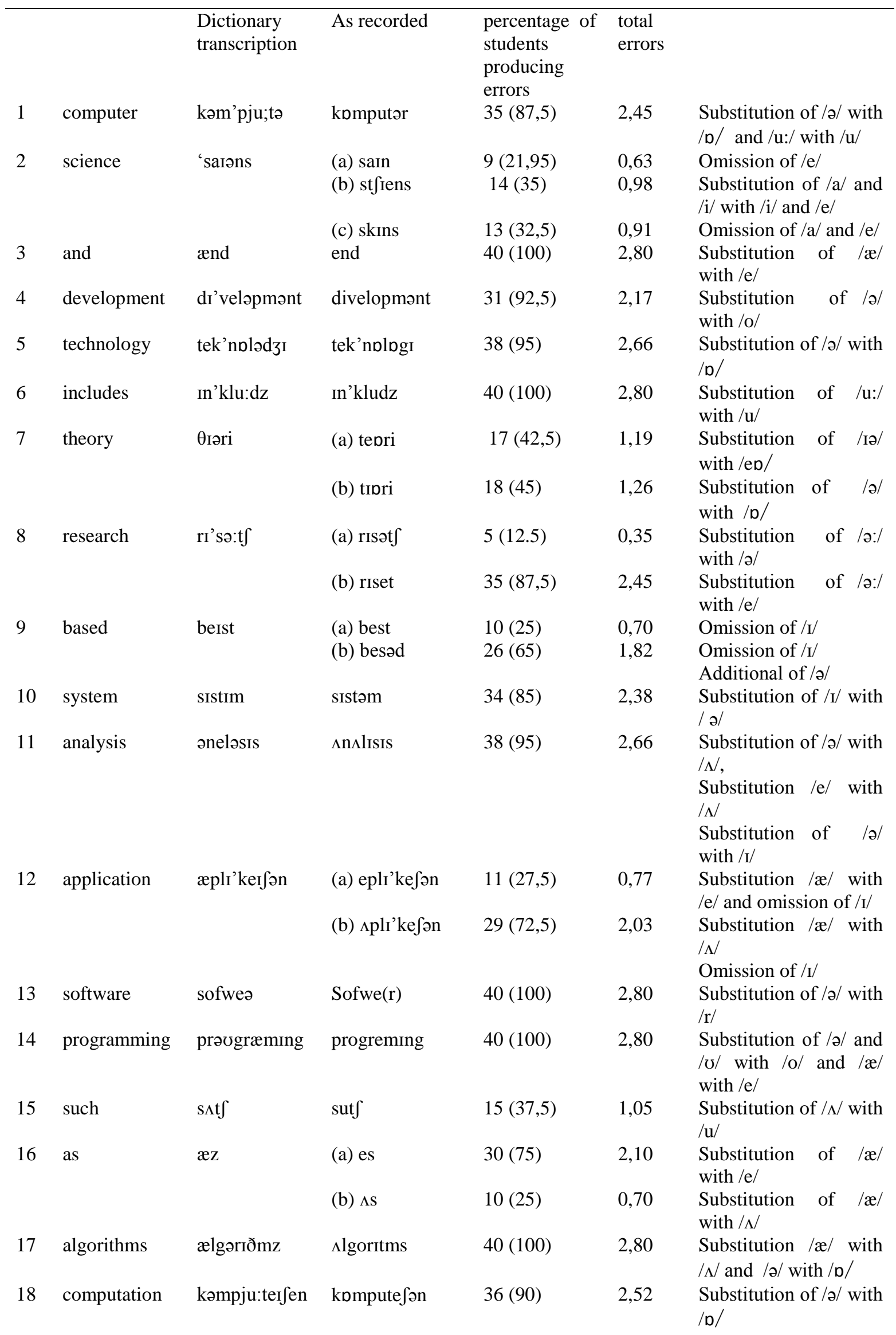




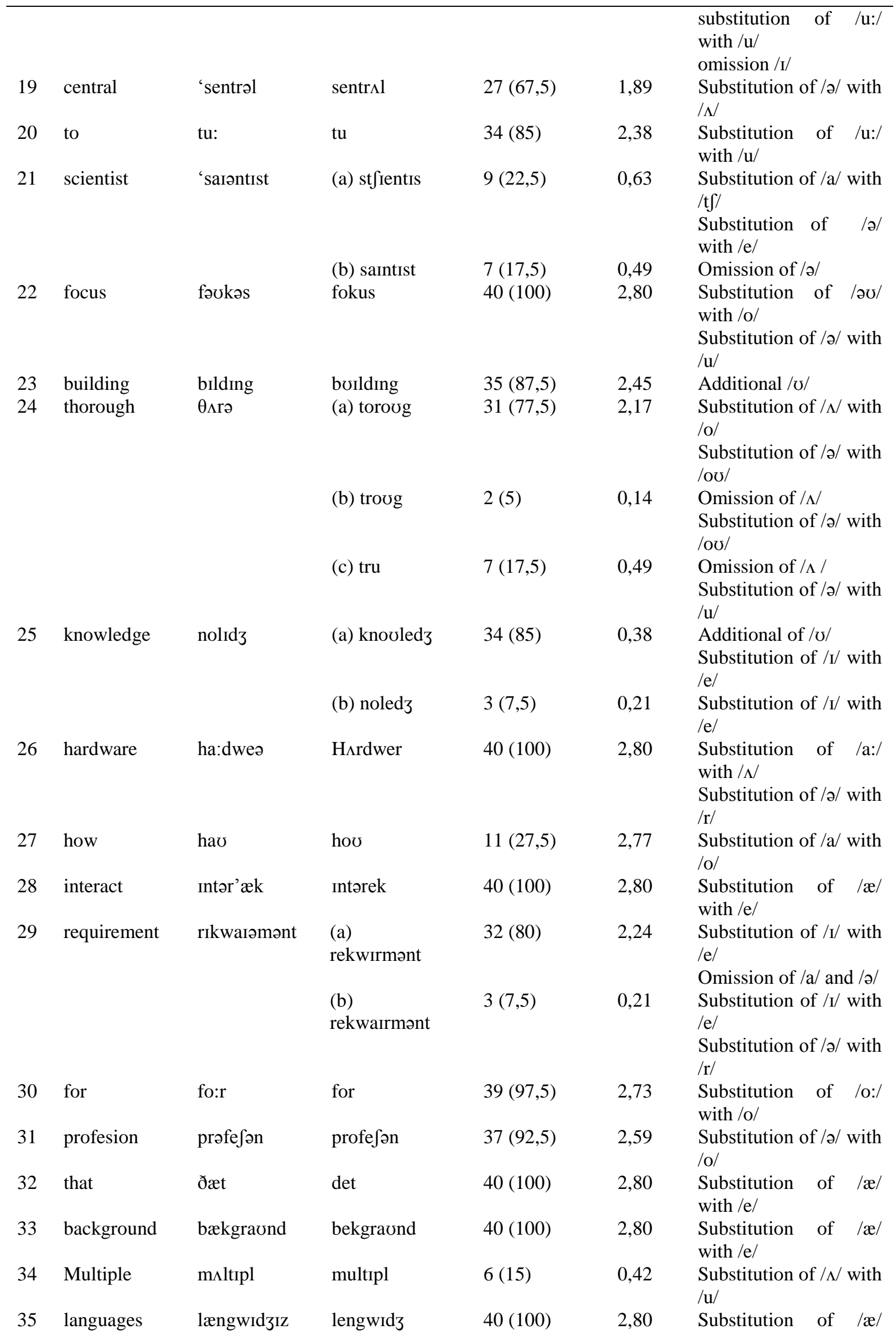




\begin{tabular}{|c|c|c|c|}
\hline 36 & Demand & dı'ma:nd & dimend \\
\hline 37 & Both & bəot & bot \\
\hline \multirow[t]{2}{*}{38} & companies & kımpənız & (a) kompər \\
\hline & & & (b) kımpe \\
\hline 39 & Addition & ə’dIfən & e'difən \\
\hline 40 & networking & netwə:king & $\begin{array}{l}\text { (a) } \\
\text { netwo(r)kI } \\
\text { (b) }\end{array}$ \\
\hline \multirow[t]{2}{*}{41} & $\begin{array}{l}\text { administratio } \\
\mathrm{n}\end{array}$ & $\begin{array}{l}\text { administreifa } \\
\mathrm{n}\end{array}$ & \\
\hline & & & $\begin{array}{l}\text { (b) } \\
\text { edministre }\end{array}$ \\
\hline \multirow[t]{2}{*}{42} & Plus & $\mathrm{pl} \Lambda \mathrm{s}$ & (a) plus \\
\hline & & & (b) plas \\
\hline \multicolumn{3}{|c|}{ TOTAL } & 58 \\
\hline \multicolumn{4}{|c|}{$\begin{array}{l}\text { As can be seen on the table, forth } \\
\text { column shows how the students } \\
\text { pronounced the words incorrectly while } \\
\text { those words should be pronounced as } \\
\text { those on the previous column. The } \\
\text { identification of errors then explained } \\
\text { on the last column. The fifth column } \\
\text { shows the number of students produced } \\
\text { the incorrect pronunciation of vowels. } \\
\text { This column also completed with the } \\
\text { percentage of students producing each } \\
\text { error. Simple counting is used on this } \\
\text { calculation: }\end{array}$} \\
\hline
\end{tabular}

$\frac{\mathrm{N} \mathrm{X} 100}{\mathrm{P}}$

Note:

$\mathrm{N}$ : number of students producing errors

$\mathrm{P}$ : number of population

Example: (datum 1) $\frac{35}{40} \times 100=87,5 \%$ with /e/

Omission of /I/

Substitution of /a:/with /e/

2,80 Substitution of /əv/ with /o/

3,92 Substitution of /a/ with /o/

0,49 Substitution of $/ \mathrm{a} /$ with le/

2,17 Substitution of /a/ with

$31(85) \quad 2,17 \quad$ le/

$37(92,5) \quad 2,59 \quad$ Substitution of /ə:/

$3(7,5) \quad 0,21 \quad \begin{array}{ll}\text { Sith } / 0 / \\ \text { Substitution of /ə:/ }\end{array}$

$33(82,5) \quad 2,31$

with / a /

2,31 Substitution of /a/ with

$/ \Lambda /$

Omission of $/ \mathrm{I} /$

$7(17,5) \quad 0,49 \quad$ Substitution of $/ 2 /$ with

/e/

Omission of /I/

$1(2,5) \quad 0,07$

$27(67,5) \quad 1,89$

1.430

100

It means that 35 of 40 students or $87,5 \%$ of respondents pronounced /kpmputor/ for word "Computer".

The sixth column gives information about the percentage of each error. There are totally 1.430 errors made by 40 students while pronouncing vowels that appear in 42 words. Every single error produced by students is listed and then calculated in order to find the frequency. The calculation is formulated as follow:

\section{Number of Error Items X 100 Total Number of Errors}

Example: (datum 36) $40+40 \times 100=$ $2,80 \%$

\section{0}

It means that among of 1,430 errors made by 40 students while pronouncing vowels, 40 or $2,80 \%$ of them are errors in pronouncing word "Demand" / dı'ma:nd/ with /dimend/ by Substituting /a:/ with /e/. 
Based on the table, we can clearly assume that there are some typical errors made by the students. The writer has analyzed the data and finally came up with the following classification of errors regards to the factors probably causing the production of those errors:

1. Errors due to the absence of certain English vowels in students' native language (Bahasa) so they tend to produce the most resemble vowels according to their native language (Bahasa). This kind of error can be seen in data $3,12 \mathrm{a}, 12 \mathrm{~b}, 14,16 \mathrm{a}$, $16 \mathrm{~b}, 17,28,32,33$, and 35 where students pronounced /e/ as /æ/ because Bahasa has no vowel /æ/, and the most resemble to that vowel in Bahasa is /e/. The number of students producing this error is undoubtedly high, it is approximately $100 \%$ error for every words containing vowel /æ/. While the percentage of errors in this term is $25,2 \%$ or more than a quarter of total errors are because of the absence of vowel /æ/ in Bahasa. It means that all of students could not pronounce /æ/ correctly because they have no sufficient knowledge about English vowels, especially /æ/ which is indeed unnatural to Indonesian tongue, and surely hard to be produced by Indonesian. The absence of certain English vowels in Bahasa that may contribute to errors production also can be seen in data 6, 8a, 18, 20, 26, 30, and 40b. There is a concept of short and long vowels in English, but there is no such thing in Bahasa. On the data mentioned previously, long vowels of English such as /u:/, /ə:/, /a:/, and /o:/ are replaced with another vowels like /u/, /o/, /e/, / $/$ and /o/ which are more familiar to
Indonesian. The percentage of errors in this term is $13,8 \%$, tough it is not high enough compared to the percentage of error in pronouncing vowel /æ/ but it is quite contributive. Totally, there are $39 \%$ errors occur due to the absence of certain English vowels in students' native language (Bahasa).

2. Errors due to the direct interference of students' native language (Bahasa). There are some English vocabularies on the text similar to words in Bahasa. It comes as the result of borrowing words in translation engineering, where some words in Source Language, in this case English, are borrowed into Target Language, Bahasa and being permanently naturalized and familiar to Indonesian students', both receptively and productively. When students encounter this kind of words, students tend to pronounce them the way they are pronounced in Bahasa. This error can be seen on data $1,2 \mathrm{a}, 5,7 \mathrm{a}, 8 \mathrm{~b}$, $10,11,19,21 \mathrm{~b}, 22$, which share $19,6 \%$ of total errors

3. Errors due to the inconsistence of English letters and sounds. Unlike Bahasa, English letters and sounds are frequently different while pronounced as a word. This inconsistence would provide a wide chance for Indonesian students producing errors. For example, in data 2, the word 'science' consists of words s, c, i, e, n, c, e, which are seemingly refers to the sounds /s/, $/ \mathrm{t} \mathrm{f} /, / \mathrm{i} /, / \mathrm{e} /, / \mathrm{n} /, / \mathrm{s} /$, but in fact, this word is pronounced as /saiəns/. There are some unpredictable appearances or omissions of sounds here as well as no certain pattern indicating that sound $/ \mathrm{t} /$ will always be replaced by $/ \mathrm{a} /$. Indonesian students will be easily confused of 
this inconsistency and unpredictable pattern as can be seen on data $2 b, 4$, 7b, 9a, 9b, 13, 15, 21a, 23, 24a, 24b, 24c, 25a, 25b, 26, 27, 29a, 29b, 31, 34, 37, 38a, 40a, and 41a which share precisely $33,07 \%$ percentage of total errors.

4. Errors due to the wrong hypothesis built by the students as the result of over generalization application. In any cases, students with limited knowledge about English sounds would likely to generalize certain concept of English sounds and apply it inappropriately. For example, students are accustomed to sound $/ \mathrm{k} /$ as reference of letter ' $c$ ' as those in the words; cat, car, school, scout, scary, and many more, which are familiar to the students. Data $2 \mathrm{c}$ shows the over generalization made by some students in pronouncing word "science" with /skins/ where it is actually should be pronounced as /sarəns/. In this case, students substituted sounds /a/ with $/ \mathrm{k} /$ as they assumed that letter ' $c$ ' will always be pronounced as $/ \mathrm{k} /$, they also omitted sounds /o/. Another case shows that students are used to relating letters $\mathrm{A}$ in the beginning or in the middle of word with vowel /e/ which is the closest one to the right vowel /æ/, just like the word "man" which is usually pronounced $/ \mathrm{men} /$, or /bet/ for "bat". In accordance to this concept, students then built an over generalization concept on data 36 , where the word "demand" is pronounced as /dimend/ instead of /dı'ma:nd/. The typical error also found on data 38b, 39, 41b and 42b. However this errors is a minor which share only $8,33 \%$ of total errors.

Referring to Richard (as cited in Heydari and Bagheri, 2012) errors 1 and 2 are classified as Interlingual Errors, because errors are produced as the result of students' native language interference. While errors 3 and 4 are classified as Intralingual and Developmental Errors, errors occur during the learning process of the second language at a stage when the learners have not really acquired the knowledge, and sometimes it is more likely caused by the difficulty or the problem of language itself. As we can see, the most dominant errors made by the student while pronouncing English vowels is Interlingual Errors $(58,6 \%)$ followed by Intralingual and Developmental Errors (41,4\%).

\section{CONCLUSION}

Data analysis shows that the difference of language features between English and Bahasa especially in the field of sounds, are proven to be the dominant problem for the students in pronouncing English Vowels. Students' native language (Bahasa) seems to have strong influence and causes difficulties for students in the process of recognizing, determining, and producing English vowels. As stated by Pallawa and Alam (2013) that teaching English sounds to Indonesian students creates many problems, one of which is the constant interference of the native language systems of the students on that of the target language 
The writer hopes this research can be an alternative reference for the further researches on the same field. As for the English Teacher, especially those who teach English at Elementary school where English is firstly introduced to Indonesian students, the writer hopes that pronunciation would be taught effectively, students must be told to be aware of the different sounds between English and Bahasa, so that thes students will be able to pronounce English sounds naturally.

\section{REFERENCES}

Afifah, L. (2014). An Analysis of Student's Pronunciation Error in Reading Texts at The Sixth Grade Students of SDN Cisauheun Bandung Barat. Bandung: STKIP Siliwangi

Ali, E. M. T. (2015). The elimination of pronunciation problems of English vowels of Saudi students of English resulting from complex letter-sound relationship. International Journal of Language and Literature, 3(1), 35-40.

Frijuniarsi, N. (2016). Syntactical error analysis on students' translations from Indonesian into English text. Deiksis, 8(3).

Gilkajani, A. P. (2012). The significance of pronunciation in English language teaching. Journal of English Language Teaching, 5(4).

Hassan, E. M. I. (2014). Pronunciation problems: a case study of English language students at Sudan University of Science and Technology. Journal English
Language and Literature Studies, 4(4).

Heydari, P., \& Bagheri, M. S. (2012). Error analysis: sources of 12 learners' errors. Journal Theory and Practice in Language Studies, 2(8).

Husada, H. S. (2007). The second language acquisition of English concord. TEFLIN Journal, 18(1).

Jones, D. (1997). An outline of English Phonetics. Cambridge; Cambridge University Press.

Nurjanah, Doni, A., \& Dwiastuty, N. (2017). Error analysis of the use of questions words in English sentence. Scope: Journal of English Language Teaching, 2(1).

Pallawa, B. A., \& Alam, A. F. A. (2013). A comparative analysis between English and Indonesian phonological systems. OJS version of International Journal of English Language Education, 1(3).

Yiing, I. K. C. (2011). An Analysis of Pronunciation Errors in English of Six Utar Chinese Studies Undergraduates, Bachelor Thesis. Perak, Malaysia: University of Tunku Abdul Rahman. 